\title{
PERANAN MOTIVASI INTRINSIK DAN MOTIVASI EKSTRINSIK TERHADAP MINAT PERSONEL BHABINKAMTIBMAS POLRES KUPANG KOTA
}

\author{
Zet Ena ${ }^{1}$, Sirda H. Djami \\ Fakultas Ekonomi, Universitas Kristen Artha Wacana Kupang \\ Corresponding author: zetena@gmail.com
}

\begin{abstract}
ABSTRAK
Dalam pemenuhan kualitas sumber daya manusia maka pemerintah membuka peluang-peluang bagi setiap aparatur Negara untuk mengikuti pendidikan. Berkaitan dengan upaya tersebut maka pemerintah melalui setiap lembaga khususnya Kepolisian Negara Republik Indonesia untuk meningkatkan SDM melalui pendidikan Kejuruan dan Pendidikan Pengembangan Sekolah Inspektur (SIP). Pendidikan ini sangat terbuka luas bagi setiap anggota Polri yang berminat untuk melanjutkan pendidikan.Pendidikan sangatlah penting dalam pengembangan Sumber Daya Manusia, dimana dalam pendidikan terdapat juga pedidikan karakter bagi setiap individu.Pendidikan berperan penting sebagai motivasi dalam peningkatan kecakapan kemampuan seorang individu agar menjadi manusia yang berkualitas. Tujuan penelitian ini untuk mengetahui Bagaimana Peranan Motivasi intristrik terhadap Minat Personel Bhabinkamtibmas Polres Kupang Kota untuk Mengikuti pendidikan, Dan Bagaimana Peranan Motivasi Ekstrinstik terhadap Minat Personel Bhabinkamtibmas Polres Kupang Kota untuk Mengikuti pendidikan.

Hasil dari penelitian ini menunjukan berdasarkan korelasi spearman sebesar 0,082 yang bertandakan nilai positif artinya semakin tinggi Motivasi Instrinstik seorang anggota Personel Bhabinkamtibmas Polres Kupang Kota, maka semakin tinggi motivasi yang lahir dari dalam diri seorang anggota untuk meningkatkan minat mengikuti pendidikan Sehingga hipotesis $\left(H_{1}\right)$ yang menyatakan bahwa Motivasi Instrinsik yang kuat dapat meningkatkan minat pendidikan bagi Personel Bhabinkamtibmas Polres Kupang Kota. Dari hasil uji SPSS didapatkan koefesien korelasi Spearman's sebesar 0,249 yang bertandakan nilai negative artinya nilai negatif disni menunjukan bahwa peranan Motivasi ekstrinstik tidak dapat merangsang atau menstimulus seorang anggota Personel Bhabinkamtibmas untuk meningkatkan minat mengikuti pendidikan. Sehingga untuk hasil pengujian hipotesis $2\left(\mathrm{H}_{2}\right)$ Ditolak. Dimana Motivasi ekstrinsik yang kuat tidak dapat meningkatkan minat pendidikan bagi Personel Bhabinkamtibmas Polres Kupang Kota.
\end{abstract}

Kata kunci : Motivasi intrinsik,motivasi ekstrinsik

\section{PENDAHULUAN}

Dalam setiap upaya pemerintah untuk pemenuhan kualitas Sumber Daya Manusia maka pemerintah membuka peluang-peluang bagi setiap aparatur Negara untuk mengikuti pendidikan. Berkaitan dengan upaya tersebut maka pemerintah melalui setiap lembaga khususnya Kepolisian Negara Republik Indonesia untuk meningkatkan SDM melalui pendidikan Kejuruan dan Pendidikan Pengembangan Sekolah Inspektur (SIP). 
Pendidikan ini sangat terbuka luas bagi setiap anggota Polri yang berminat untuk melanjutkan pendidikan.Pendidikan sangatlah penting dalam pengembangan Sumber Daya Manusia, dimana dalam pendidikan terdapat juga pedidikan karakter bagi setiap individu.Pendidikan berperan penting sebagai motivasi dalam peningkatan kecakapan kemampuan seorang individu agar menjadi manusia yang berkualitas. Motivasi dalam pendidikan terdiri dari dua jenis yaitu motivasi instrinstik dan ekstrinstik (Prayitno,1989). Motivasi ekstrinstik merupakan motivasi dari dalam dan motivasi ekstrinstik merupakan motivasi atau dorongan dari luar. Sedangkan menurut menurut Uno,( $2008: 22$ ) mengatakan bahwa motivasi adalah dorongan internal dan eksternal dalam diri seseorang untuk mengadakan perubahan tingkah laku. Motivasi dapat menentukan baik tidaknya tindakan personel dalam mencapai tujuan sehingga semakin besar motivasinya akan semakin besar keinginan berusaha untuk mencapai prestasi, gigih dalam bekerja, tidak mau menyerah, giat dalam berinovasi untuk meningkatkan prestasinya. Sebaliknya, mereka yang motivasinya rendah, tampak acuh, kurang perhatian dalam bekerja dancederung tidak bergairah dalam melaksanakan tugas.Hal ini juga diungkapkan oleh Douglas McGregor.Ia membedakan 2 tipe pekerja yaitu X dan Y diman tipe $\mathrm{x}$ yaitu menyatakan bahwa orang-orang sesungguhnya malas dan tidak mau bekerja sama dan Teori Y, menyatakan bahwa orang-orang sesungguhnya energik, berorientasi kepada perkembangan, memotivasi diri sendiri, dan tertarik untuk menjadi produktif. (Griffin, 1998:260). Menurut Sardiman (2014:89) mengemukakan bahwa motivasi Intrinsik adalah motif-motif yang menjadi aktif atau berfungsinya sehingga tidak perlu rangsangan dari luar, karena dari dalam diri individu sudah ada dorongan untuk melakukan sesuatu.Sedangkan motivasi Ekstrinsik adalah motif-motif yang aktif dan berfungsi karena adanya perangsang dari luar, karena Motivasi merupakan suatu kekuatan yang dapat mendorong seseorang untuk melakukan suatu perbuatan, termaksud bekerja. Motivasi untuk bekerja adalah penting dalam melakukan kegiatan sehari-hari dikarenakan motivasi merupakan pendorong yang dapat melahirkan kegiatan seseorang.

Dalam melaksanakan tugas pokok tersebut Polri melaksanakan pengaturan, penjagaan, pengawalan, dan patroli terhadap kegiatan masyarakat dan pemerintah sesuai kebutuhan, menyelenggarakan segala kegiatan dalam menjamin keamanan ketertiban dan kelancaran lalu lintas di jalan,membina masyarakat untuk meningkatkan partisipasi masyarakat, kesadaran hukum masyarakat serta ketaatan warga masyarakat terhadap hukum dan peraturan perundang-undangan,turut serta dalam pembinaan hukum nasional, memelihara ketertiban dan menjamin keamanan umum, melakukan koordinasi, pengawasan, dan pembinaan teknis terhadap kepolisian khusus, penyidik pegawai negeri sipil, dan bentuk-bentuk pengamanan swakarsa,melakukan penyelidikan dan penyidikan terhadap semua tindak pidana sesuai dengan hukum acara pidana dan peraturan perundang-undangan lainnya,menyelenggarakan indentifiksi kepolisian, kedokteran kepolisian, laboratorium forensik dan psikologi kepolisian untuk kepentingn tugas kepolisian,melindungi keselamatan jiwa raga, harta benda, masyarakat, dan lingkungan hidup dari gangguan ketertiban dan bencana, termasuk memberikan bantuan dan pertolongan dengan menjunjung tinggi hak asasi manusia,melayani kepentingan warga masyarakat untuk sementara sebelum ditangani oleh instansi dan/atau pihak yang berwenang,memberikan pelayanan kepada masyarakat sesuai dengan kepentingan dalam lingkungan tugas kepolisian, serta melaksanakan tugas lain sesuai dengan peraturan perundang-undangan, yang dalam pelaksanaannya akan diatur lebih lanjut dengan Peraturan Pemerintah. 
Polres Kupang Kota dituntut untuk memiliki system manajemen personel yang baik sehingga dapat menghasilkan sumber daya manusia (SDM) yang berkualitas, oleh sebab itu untuk meningkatkan minatpersonel bhabinkamtibmas Polres Kupang harus dapat mengugah personelnya dalam peningkatan kemampuan, pengetahuan dan pengembangan karir personel-personel bhabinkamtibmas, sehingga dalam pelaksaannya tugas sehari-hari bhabinkamtibmas ini terus berkembang dengan pengetahuan yang lebih luas dalam melaksanakan tugasnya sebagai seorang pembina didalam masyarakat, namun yang menjadi masalah disini adalah sangat minim.

Penelitian ini merujuk pada penelitian Penelitian ini mengacu pada penelitian terdahulu yang dilakukan oleh Aziz, (2017)yang berjudul Pengaruh Motivasi Intrinsik dan Motivasi Ekstrinsik terhadap Prestasi Belajar Ekonomi Bisnis Kelas X Peserta Didik di SMKN 4 Makassar. Hasil penelitian ini menunjukkan terdapat pengaruh yang signifikan motivasi instrinsik dan motivasi ekstrinsik terhadap Prestasi Belajar Ekonomi Bisnis Kelas X Peserta Didik di SMKN 4 Makassar. Penelitian berikut yang dilakukan oleh Sirait (2008), Dengan judul Pengaruh Motivasi Intrinsik, Ekstrinsik terhadap Prestasi Kerja karyawan pada PT. Dahlia Dewantara Medan.Hasil penelitian menunjukkan bahwa Motivasi yang diwakili motivasi instrinsik, berpengaruh signifikan terhadap Prestasi Kerja dimana dan motivasi ekstrinsik berpengaruh secara signifikan terhadap Prestasi Kerja.Namun terdapat perbedaan antara penelitian sebelumnya dengan penelitian ini adalah penelitian sebelumnya menggunakan Prestasi kerja sebagai variabel Y, tetapi dalam penelian ini peneliti menggunakan Minat sebagai Variabel Y.Sehingga penulis ingin mengetahui lebih jauh tentang"Peranan Motivasi Intrinsik dan Motivasi Ekstrinsik terhadap MinatBhabinkamtibmas Polres Kupang Kota".

\section{LANDASAN TEORI DAN PENGEMBANGAN HIPOTESIS Minat}

Minat adalah suatu keadaan dimana seseorang mempunyai perhatian terhadap sesuatu dan disertai keinginan untuk mengetahui dan mempelajari maupun membuktikan lebih lanjut (Walgito 1981).sedangkan menurut (Witherington 1985) minat adalah kesadaran seseorang terhadap suatu objek, seseorang, situasi maupun suatu soal tertentu yang menyangkut dengan dirinya atau dipandang sebagai sesuatu yangsadar. Menurut (Jogiyanto 2007), minat berperilaku adalah keinginan (Minat) seseorang untuk melakukan perilaku diprediksi oleh sikapnya terhadap perilakunya dan bagaimana dia berpikir orang lain akan menilainya jika dia melakukan perilaku tersebut. (Slameto 1995) menyatakan Minat adalah kecenderungan jiwa yang tetap untuk memperhatikan dan mengenang beberapa aktivitas atau kegiatan.Jadi apabila seseorang berminat untuk memperhatikan suatu aktivitas dan melakukan aktivitas yang dilakukan pasti dengan dilandasi rasa senang dalam melakukannya. Jika menimbulkan rasa senang, maka seseorangdimasa yang akan 70ndepe akan secara terus - menerus ingin menggunakannya.

Fungsi Minat sangat berhubungan erat dengan perasaan dan pikiran. Manusia akan memberikan suatu penilaian, menentukan sesudah memilih pilihan yang diinginkan dan secara langsung mengambil suatu keputusan. Menurut (Saraswati 2013), minat merupakan kecenderungan hati yang tinggi terhadap sesuatu yang timbul karena kebutuhan, yang dirasa atau tidak dirasakan atau keinginan hal tertentu.Kenyataan yang sebenarnya, Minat dapat berubah-ubah sesuai dengan kehendak yang diinginkan suatu individu yang bersangkutan.Minat tidak hanya selalu bersifat tetap. Semakin 70ndepen lama waktunya, minat yang akan dialami akan terjadi 
perubahan yang semakin besar. Begitu juga sebaliknya, apabila lama waktu semakin kecil, terjadinya perubahan minat dapat diminimalisir.

Dari pengertian di atas dapat disimpulkan bahwa Minat adalah ketertarikan individu pada sesuatu yang sifatnya tetap agar lebih mengingat dan memperhatikan secara terus menerus yang diikuti dengan rasa senang untuk memperoleh sesuatu kepuasan dalam mencapai kepuasan penggunaan teknologi. Seseorang akan lebih sering menggunakan teknologi, jika kepuasan yang dirasakan memiliki manfaatnya.

Faktor-faktor yang Mempengaruhi Minat (Slameto 2003), menyatakan bahwa "Minat tidak dibawa sejak lahir, melainkan diperoleh kemudian.Minat terhadap sesuatu merupakan hasil belajar dan menyokong belajar selanjutnya".Hal ini menggambarkan bahwa minat dapat ditumbuhkan dan dikembangkan. Minat tidak akan muncul dengan sendirinya secara tiba-tiba dari dalam diri individu. Minat dapat timbul pada diri seseorang melalui proses. Dengan adanya perhatian dan interaksi dengan lingkungan, maka minat tersebut dapat berkembang.Munculnya minat ini biasanya ditandai dengan adanya dorongan, perhatian, rasa senang, kemampuan, dan kecocokan atau kesesuaian.Timbulnya minat seseorang disebabkan oleh beberapa hal, yaitu rasa tertarik atau rasa senang, perhatian dan kebutuhan.Minat timbul karena perasaan senang serta tendensi yang dinamis untuk berperilaku atas dasar ketertarikan seseorang pada jenisjenis kegiatan tertentu. Perasaan senang seseorang akan menimbulkan dorongandorongan dalam dirinya untuk segera beraktifitas.

Menurut (Smadi 2012), faktor-faktor yang menimbulkan Minat dapat digolongkan sebagai berikut :

1) Faktor kebutuhan dari dalam. Kebutuhan ini dapat berupa kebutuhan yang berhubungan dengan jasmani dankejiwaan.

2) Faktor motif sosial, timbunya Minat dalam diri seseorang dapat didorong oleh motif sosial yaitu kebutuhan untuk mendapatkan pengakuan, penghargaan dari lingkungan dimana iaberada.

3) Faktor emosional. Faktor ini merupakan ukuran intensitas seseorang dalam menaruh perhatian terhadap sesuatu kegiatan atau objektertentu.

\section{Motivasi}

Kehidupan seorang manusia secara alamiah selalu di hubungkan dengan motivasi, dimana motivasi adalah 'alasan' yang mendasari sebuah perbuatan yang dilakukan oleh seorang individu. Seseorang dikatakan memiliki motivasi tinggi dapat diartikan orang tersebut memiliki 71ndepen yang sangat kuat untuk mencapai apa yang diinginkannya dengan mengerjakan pekerjaannya yang sekarang.

Menurut Hasibuan (2007), motivasi berasal dari kata latin movere yang berarti dorongan atau pemberian daya penggerak yang menciptakan kegairahan kerja seseorang agar mereka mau bekerja sama, bekerja efektif, dan terintegrasi dengan segala daya upayanya untuk mencapai kepuasan. Arti motivasi juga dapat didefinisikan sebagai semua hal yang menimbulkan dorongan atau semangat di dalam diri seseorang untuk mengerjakan sesuatu.Dengan demikian motivasi merupakan dorongan yang terdapat dalam diri seseorang untuk berusaha mengadakan perubahan tingkah laku yang lebih baik dalam memenuhi kebutuhanya, (Uno, 2008: 3). Banyak istilah yang digunakan untuk mengambarkan atau menyebut motivasi atau Motif seperti kebutuhan (need), desakan (urge), keinginan (wish) dan dorongan (drive).Banyak sekali teori-teori motivasi yang dikemukan oleh para ahli.Menurut Siagian (1995) motivasi merupakan daya pendorong yang mengakibatkan seorang anggota organisasi agar mau dan rela untuk mengerahkan kemampuannya dalam bentuk keahlian atau keteampilan tenaga dan 
waktunya untuk menyelenggarakan berbagai kegiatan yang menjadi tanggung jawabnya dan menunaikan kewajibanya, dalam rangka pencapaian tujuan dan berbagai sasaran organisasi yang telah ditentukan sebelumnya. Menurut Moorhead dan griffin (2013) Motivasi merupakan keinginan, harapan, tujuan, sasaran, kebutuhan, dorongan, motivasi dan insentif.Menurut Buchbinder,dkk (2007) motivasi adalah proses terbentuknya motif yang menyebabkan seseorang melakukan aksi. Sedangkan menurut Openstax College (2014) Motivasi adalah gabungan dari faktor internal seperti tujuan hidup dan lain-lain. Dikatakan dalam Prayitno, (1989:10) ada dua tipe motivasi yaitu (1) motivasi intrinsik, dan (2) motivasi ekstrinsik.

1. Motivasi Intrinsik

Thornburgh dalam Prayitno, (1989:10) berpendapat bahwa motivasi intrinsik adalah keinginan bertindak yang disebabkan faktor pendorong dari dalam diri (internal) individu. Individu yang digerakkan oleh motivasi intrinsik, baru akan puas kalau kegiatan yang dilakukan telah mencapai hasil yang terlibat dalam kegiatan itu. Sedangkan menurut Gunarsa, (2008:50) motivasi intrinsik merupakan dorongan atau kehendak yang kuat yang berasal dari dalam diri seseorang. Semakin kuat motivasi intrinsik yang dimiliki oleh seseorang, semakin besar kemungkinan ia memperlihatkan tingkah laku yang kuat untuk mencapaitujuan.

2. Motivasi Ekstrinsik

Motivasi ekstrinsik dinamakan demikian karena tujuan utama individu melakukan kegiatan adalah untuk mencapai tujuan yang terletak di luar aktivitas belajar itu sendiri, atau tujuan itu tidak terlibat di dalam aktivitas belajar. Menurut Gunarsa, (2008:51) yang dimaksud dengan motivasi ekstrinsik adalah segala sesuatu yang diperoleh melalui pengamatan sendiri, ataupun melalui saran, anjuran atau dorongan dari oranglain.

a. Faktor-faktor yang mempengaruhi motivasi

Aspek-aspek yang mempengaruhi motivasi atau menentukan intensitas dari motivasi dikenal sebagai dimensi motivasi (Gunarsa, 2008:52). Sedangkan menurut Uno,( 2008 : 22 ) mengatakan bahwa motivasi adalah dorongan internal dan eksternal dalam diri seseorang untuk mengadakan perubahan tingkah laku. Aspek-aspek yang mempengaruhi motivasi atau menentukan intensitas dari motivasi dikenal sebagai dimensi motivasi (Gunarsa, 2008:52). Yang mempunyai Indikator Hasibuan (2007) berpendapat bahwa ada beberapa faktor dari motivasi intrinsik, antara lain : tanggung jawab, penghargaan, pekerjaan itu sendiri, pengembangan dan kemajuan

Aspek-aspek yang mempengaruhi motivasi atau menentukan intensitas dari motivasi dikenal sebagai dimensi motivasi (Gunarsa, 2008:52).yang mempuyai indikator sebagai berikut, Faktor-faktor yang termasuk dalam motivasi ekstrinsik menurut Manullang (2001) adalah : gaji, kebijakan, hubungan kerja, lingkungan kerja, supervise. Dari uraian tersebut maka dapat disusun hipotesis sebagai berikut :

$\mathrm{H}_{1}$ : Motivasi intrinstik yang kuat dapat mengkatkan minat untuk mengikuti pendidikan bagi Personel Bhabinkamtibmas Polres Kupang Kota

$\mathrm{H}_{2}$ : Motivasi eksrtintik yang kuat dapat mengkatkan minat untuk mengikuti pendidikan bagi personel Bhabinkamtibmas Polres Kupang Kota 


\section{MODEL PENELITIAN}

Dalam penelitian ini peneliti akan melihat bagaimana pengaruh motivasi instrinsik dan motivasi ekstrinstik terhadap prestasi kerja Bhabinkamtibmas Polres Kupang Kota . Kerangka penelitian dalam penelitian ini sebagai berikut:

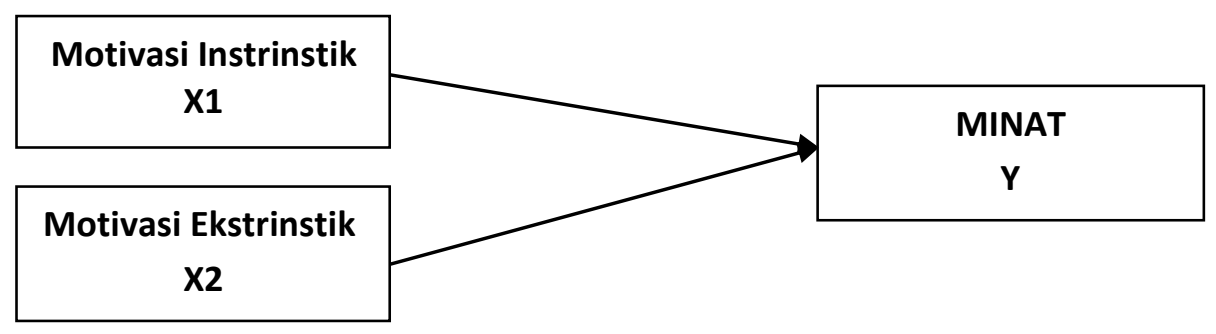

Gambar 1. Kerangka Pikir Penelitian

\section{METODE PENELITIAN}

\section{Populasi dan Sampel}

Populasi dalam penelitian ini adalah seluruh personel Bhabinkamtibmas Polres Kupang Kota Sebanyak 50 Orang. Sampel dalam penelitian ini adalah keseluruhan dari populasi yaitu 50 orang yang merupakan anggota personel Bhabinkamtibmas Polres Kupang Kota.

\section{Teknik Analisis Data}

Analisis lanjutan yang digunakan dalam penelitian ini Analisis ini untuk mengetahui peranan Motivasi Instrinsik dan Motivasi Ekstrinsik terhadap minat personel bhabinkamtibmas Polres Kupang Kota dengan Uji beda dua mean dapat dilakukan dengan menggunakan uji $\mathrm{Z}$ atau uji $\mathrm{T}$. uji $\mathrm{Z}$ dapat digunakan bila standar deviasi populasi $(\sigma)$ diketahui dan jumlah sampel besar $(\geq 30)$. Apabila kedua syarat tersebut tidak terpenuhi, maka dilakukan uji T. pada umumnya nilai $\sigma$ sulit diketahui, sehingga uji beda dua mean biasanya menggunakan Uji T (T-Test). Bentuk ujinya adalah sebagai berikut:

$$
\begin{aligned}
& \mathrm{T}=\frac{\mathrm{X} 1-\mathrm{X} 2}{\mathrm{Sp} \sqrt{(\mathrm{l} / \mathrm{n} 1)+(1 / \mathrm{n} 2)}} \\
& \mathrm{Sp}^{2}=\frac{(\mathrm{n} 1-1) \mathrm{S}_{1}{ }^{2}+(\mathrm{n} 2-1) \mathrm{S}_{2}{ }^{2}}{\mathrm{n} 1+\mathrm{n} 2-2} \\
& \mathrm{df}=\mathrm{n} 1+\mathrm{n} 2-2 \\
& \mathrm{~F}=\frac{\mathrm{S}_{1}{ }^{2}}{\mathrm{~S}_{2}{ }^{2}} \\
& \mathrm{df}=\mathrm{n} 1-1 \text { dan } \mathrm{df}_{2}=\mathrm{n} 2-1
\end{aligned}
$$


Ket:

$\mathrm{n} 1=$ jumlah sampel kelompok Motivasi Instrinstik

n2= jumlah sampel kelompok Motivasi Instrinstik

$\mathrm{S} 1=$ Standar Devisiasi Sampel Kelompok Motivasi Instrinstik

S2 = standar deviasi sampel kelompok Motivasi ekstrinstik

\section{HASIL DAN PEMBAHASAN \\ Hasil Uji Korelasi}

\begin{tabular}{|c|c|c|c|c|c|}
\hline \multicolumn{6}{|c|}{$\begin{array}{c}\text { Tabel } 1 \\
\text { Hasil Uji Korelasi } \\
\text { Correlations }\end{array}$} \\
\hline & & & $\begin{array}{c}\text { Motivasi } \\
\text { Instrinstik }\end{array}$ & $\begin{array}{c}\text { Motivasi } \\
\text { ekstrinstik }\end{array}$ & Minat \\
\hline \multirow{6}{*}{$\begin{array}{l}\text { Spearman's } \\
\text { rho }\end{array}$} & \multirow{2}{*}{ Motivasi Instrinstik } & $\begin{array}{l}\text { Correlation } \\
\text { Coefficient }\end{array}$ & 1,000 &, $539^{\star *}$ & ,082 \\
\hline & & $\begin{array}{l}\text { Sig. (2-tailed) } \\
N\end{array}$ & 50 & $\begin{array}{r}, 000 \\
50\end{array}$ & $\begin{array}{r}, 003 \\
50\end{array}$ \\
\hline & \multirow{2}{*}{ Motivasi ekstrinstik } & $\begin{array}{l}\text { Correlation } \\
\text { Coefficient }\end{array}$ &, $539^{* *}$ & 1,000 &,- 249 \\
\hline & & $\begin{array}{l}\text { Sig. (2-tailed) } \\
N\end{array}$ & $\begin{array}{r}, 000 \\
50\end{array}$ & 50 & $\begin{array}{r}, 081 \\
50\end{array}$ \\
\hline & \multirow{2}{*}{ Minat } & $\begin{array}{l}\text { Correlation } \\
\text { Coefficient }\end{array}$ & 082, &,- 249 & 1,000 \\
\hline & & $\begin{array}{l}\text { Sig. (2-tailed) } \\
\mathrm{N}\end{array}$ & $\begin{array}{r}, 003 \\
50\end{array}$ & $\begin{array}{r}, 081 \\
50\end{array}$ & 50 \\
\hline
\end{tabular}

Sumber : Data primer yang diolah, tahun 2020

Dari hasil analisis diatas, didapatkan nilai signifikansi anatara variabel Motivasi Instrinstik (X1) terhadap Minat sebesar 0,003. Dengan korelasi Spearman nilai 0,003 $<0,005$ Sehingga dari hasil penelitian ini menunjukan Motivasi Insrtintik yang kuat dapat mingkatkan minat untuk mengikuti pendidikan bagi Personel Bhabinkamtibmas Polres Kupang Kota untuk Mengikuti pendidikan. Selanjutnya untuk Variabel Motivasi Ekstrinstik (X2) terhadap minat (Y) sebesar 0,081. Hasil ini menunjukan bahwa Motivasi ekstrinsik tidak memiliki hubungan yang kuat dalam meningkatkan minat pendidikan bagi Personel Bhabinkamtibmas Polres Kupang Kota.

\section{Pengujian Hipotesis}

Motivasi Insrtintik yang kuat dapat mingkatkan minat untuk mengikuti pendidikan bagi Personel Bhabinkamtibmas Polres Kupang Kota

Dari data output spss yang telah disajikan dalam tabel 1 didapatkan koefesien korelasi Spearman's sebesar 0,082 yang bertandakan nilai positif artinya semakin tinggi Motivasi Instrinstik seorang anggota Personel Bhabinkamtibmas Polres Kupang Kota, maka semakin tinggi motivasi yang lahir dari dalam diri seorang anggota untuk meningkatkan minat mengikuti pendidikan. Sehingga dari hasil uji di tabel 1 menunjukan bahwa Hipotesis $1\left(\mathrm{H}_{1}\right)$ Diterima atau Motivasi Insrtintik yang kuat dapat mingkatkan minat untuk mengikuti pendidikan bagi Personel Bhabinkamtibmas Polres Kupang Kota. 


\section{Motivasi Insrtintik yang kuat dapat mingkatkan minat untuk mengikuti pendidikan bagi Personel Bhabinkamtibmas Polres Kupang Kota}

Responden personel Personel Bhabinkamtibmas Polres Kupang Kota memberikan pernyataan yang cukup baik terhadap indikator yang digunakan. Ditunjukkan dengan hasil olahan data dimana, berdasarkan korelasi spearman sebesar 0,082 yang bertandakan nilai positif artinya semakin tinggi Motivasi Instrinstik seorang anggota Personel Bhabinkamtibmas Polres Kupang Kota, maka semakin tinggi motivasi yang lahir dari dalam diri seorang anggota untuk meningkatkan minat mengikuti pendidikan Sehingga hipotesis $\left(\mathrm{H}_{1}\right)$ yang menyatakan bahwa Motivasi Instrinsik yang kuat dapat meningkatkan minat pendidikan bagi Personel Bhabinkamtibmas Polres Kupang Kota.

Minat merupakan pemusatan perhatian terhadap suatu objek sehingga ada rasa suka dan senang sebagai dasar untuk belajar yang menjadi rutinitas. Kecintaan atau rasa suka seseorang terhadap pelajaran membuat seseorang lebih bergairah dan bersemangat dalam belajar. Hal tersebut ditandai dengan dijadikannya belajar sebagairutinitas, hobby, dan kesenangan. Hasrat untuk mengikuti pendidikan bagi anggota Personel Bhabinkamtibmas Polres Kupang Kota untuk mengikuti pendidikan sangatlah kuat hubungannya. Hal ini akan lebih baik, bila dibandingkan segala sesuatu kegiatan yang tanpa maksud. Hasrat untuk mengikuti pendidikan berarti pada diri Personel Bhabinkamtibmas Polres Kupang Kota itu memang ada motivasi untuk mengikuti pendidikan dan pelatihan, sehingga sudah barang tentu hasilnya akan lebih baik. Menumbuhkan kesadaran kepada agar merasakan pentingnya tugas menerimanya sebagai tantangan sehingga bekerja keras dengan mempertaruhkan harga diri, adalah sebagai salah satu bentuk motivasi yang cukup penting. Seseorang akan berusaha dengan segenap tenaga untuk mencapai prestasi yang baik dengan harga dirinya.

Rumusan tujuan yang diakui dan diterima baik oleh Personel Bhabinkamtibmas Polres Kupang Kota, akan menjadi alat motivasi yang sangat penting. Sebab dengan memahami tujuan yang harus dicapai karena merasa sangat berguna dan menguntungkan, maka akan timbul gairah untuk terus belajar. Hasil penelitian menunjukkan Motivasi Instrinsik yang kuat dapat meningkatkan minat pendidikan bagi Personel Bhabinkamtibmas Polres Kupang Kota dapat menjadikan ajang angota personel untuk belajar merupakan tantangan sehingga mereka dengan segenap kekuatan menjaga harga dirinya di hadapan teman-temannya. Hasil penelitian ini sejalan dengan penelitian yang dilakukan oleh Arif Budianto (2013) dengan judul "Pengaruh Motivasi Belajar Intrinsik dan Minat Belajar terhadap Prestasi Belajar Mahasiswa Pendidikan Administrasi Perkantoran Angkatan 2010 Fakultas Ekonomi Universitas Negeri Yogyakarta", hasil penelitiannya menunjukkan bahwa terdapat pengaruh positif dan signifikan motivasi belajar intrinsik terhadap prestasi belajar mahasiswa Program Studi Pendidikan Administrasi Perkantoran angkatan 2010 FE UNY.

Motivasi ekstrinsik yang kuat dapat mingkatkan minat untuk mengikuti pendidikan bagi Personel Bhabinkamtibmas Polres Kupang Kota.

Dari data output spss yang telah disajikan dalam tabel 4.2 didapatkan koefesien korelasi Spearman's sebesar -0,249 yang bertandakan nilai negative artinya nilai negatif disni menunjukan bahwa peranan Motivasi ekstrinstik tidak dapat merangsang atau menstimulus seorang anggota Personel Bhabinkamtibmas untuk meningkatkan minat mengikuti pendidikan. Sehingga untuk hasil pengujian hipotesis $2\left(\mathrm{H}_{2}\right)$ Ditolak. Hasil ini juga mendukung penelitian Murti (2013) yang menyimpulkan bahwa motivasi ekstrinsik tidak berpengaruh signifikan terhadap kinerja karyawan. 
Motivasi ekstrinsik dinamakan demikian karena tujuan utama individu melakukan kegiatan adalah untuk mencapai tujuan yang terletak di luar aktivitas belajar itu sendiri, atau tujuan itu tidak terlibat di dalam aktivitas belajar. Menurut Gunarsa, (2008:51) yang dimaksud dengan motivasi ekstrinsik adalah segala sesuatu yang diperoleh melalui pengamatan sendiri, ataupun melalui saran, anjuran atau dorongan dari oranglain. Motivasi ekstrinsik adalah pendorong kerja yang bersumber dari luar diri pekerja sebagai individu berupa suatu kondisi yang mengharuskannya melaksanakan pekerjaan secara maksimal (Nawawi, 2001).

Kurangnya minat bhabinkamtibmas dalam mengikuti pendidikan dan pengembangan diri juga dilatarbelakangi oleh banyak faktor diantaranya anggota sudah terlalu nyaman dengan situasi dan kondisi diwilayah binaan yang kondusif dan lebih santai serta Memiliki hubungan atau kedekatan yang baik dengan masyarakat desa binaan dalam menjalankan tugas sehingga untuk mengikuti pendidikan bukan pilihan bagi para anggota Personel Bhabinkamtibmas Polres Kupang Kota.

Hal lain yang juga mempengaruhi anggota Personel Bhabinkamtibmas Polres Kupang Kota adalah Kurangnya motivasi dari luar karena Faktor keluarga, lingkungan dan hal lainnya juga pengaruh financial. Dalam mengikuti pendidikan dan pengembangan membutuhkan waktu yang cukup lama minimal satu bulan untuk pendidikan kejuruan dan maksimal delapan bulan untuk pendidikan pengembangan karir dan usia fisik dari para personel juga dari data diatas menunjukan bahwa rata sudah di atas 34 tahun sampai dengan 44 tahun yang sudah tidak memungkinkan untuk mengikuti pelatihan. Hal itu disebabkan karena pendidikan untuk personel lebih banyak kepada hal fisik.

\section{PENUTUP}

\section{Kesimpulan}

Berdasarkan hasil uji Hipotesis $\mathrm{H}_{1}$ Motivasi Instrinsik yang kuat dapat meningkatkan minat pendidikan bagi Personel Bhabinkamtibmas Polres Kupang Kota. Oleh karena itu hal yang berhubungan dengan motivasi instrinstik bagi personel bhabinkantibmas seperti Tanggung jawab, Prestasi, Penghargaan, Pengembangan lebih diperkuat lagi sehingga anggota personel lebih berminat untuk mengikuti pendidikan.

\section{DAFTAR PUSTAKA}

Hasibuan, Malayu, S.P.(1995), Manajemen Sumber Daya Manusia: Dasar dan Kunci Keberhasilan, Jakarta

Hasibuan Malayu, 2011, Manajemen Dasar, Pengertian dan Masalah, Toko Gunung Agung, Jakarta.

EdySutrisno, 2011, Manajemen Sumber Daya Manusia, Jakarta : Kencana.

Anwar Prabu Mangkunegara. 2002. Manajemen Sumber Daya Manusia Perusahaan. Bandung : PT.Remaja Rosda Karya

Manullang M.,\& Manullang M. 2001. Manajemen Sumber Daya Manusia. (edisi-1), Yogyakarta :BPFE-Yogyakarta.

Abraham H. Maslow, 2010, Motivation and Personality. Rajawali, Jakarta. 
Ph.D. Kuncoro M2009.Metode Riset untuk Bisnis Ekoomi. ed.3.Jogjakarta:PT Gelora Aksara Pratama.

SusilanaR.BBM_5.revisimodul5LandasanTeoridanHipotesis-Direktorifile.UPI.Modul Landasan Teori dan Hipotesis

Amstrong, Michael, 1990, Manajemen Sumber Daya Manusia Seri Pedoman Manajemen, (Alih Bahasa : Sofyan dan Haryanto), Jakarta: Elex Media Komputindo Kelompok Gramedia.

Armstrong, M. (1994), Manajemen Sumber Daya Manusia, Media Kompetindo, Jakarta.

Kuncoro, Mudrajad , 2001, Metode Kuantitatif (Teori dan Aplikasi untuk Bisnis dan Ekonomi), Unit Penerbit dan Percetakan AMP YKPN, Yogyakarta. 